\title{
Defibrillator til folket?
}

Plutselig, uventet hjertestans utenfor sykehus rammer årlig ca. 2500 mennesker i Norge, dvs. 50-60 per 100000 personår (1). Bare i overkant av $10 \%$ utskrives fra sykehus i live $(2,3)$. Enkel akuttbehandling avgjør - defibrillering ved letale arytmier og sikring av frie luftveier og ventilasjon ved drukning og kvelning. Tidlig defibrillering bedrer i vesentlig grad overlevelsen ved ventrikkelflimmer (4). Denne erkjennelsen ligger til grunn for utplassering av «hjertestartere» (halvautomatiske defibrillatorer) til allmenn bruk.

Apparatene er rimelige i innkjøp og enkle å bruke. Sosial- og helsedirektoratet slo i 2007 fast at det utenfor helsevesenet ikke er påkrevd med legedelegering for å benytte defibrillator (5). Norsk Resuscitasjonsråd understreker at defibrillering ved hjertestans er å oppfatte som førstehjelp og anbefaler kurs for ulike målgrupper. Noen spørsmål bør likevel stilles. Er dette alt som skal til? Hvem bør anskaffe defibrillator og hvor skal defibrillatorene plasseres? Hvor nyttige vil de være? Er det problemer med bruken?

Første spørsmål kan besvares med et klart nei. Defibrillering vil bare terminere ventrikkelflimmer eller pulsløs ventrikkeltakykardi. I noen studier har man riktignok funnet ventrikkelflimmer hos $70-80 \%$ av pasientene umiddelbart etter hjertestans $(6,7)$, men ellers har rundt halvparten asystole eller pulsløs elektrisk aktivitet (8). Disse verken skal eller kan defibrilleres. Den som anskaffer seg og bruker defibrillator bør derfor vite at den ikke alltid vil være genuint nyttig og at god basal hjerte-lunge-redning fortsatt er vesentlig.

Hvem bør så anskaffe defibrillator, og hvor skal defibrillatorene plasseres? Alle som tar seg av akutt syke, bør ha defibrillator i umiddelbar nærhet - ambulanse, legevakt, legekontor, førstehjelpsposter ved større arrangementer osv. En strategi har vært å utplassere defibrillatorer hos personell som har en form for beredskap, det gjelder vektere, brannvesen, politi, hjemmesykepleie. Samlet vil disse sammen med ambulanse og legevakt i stor grad være på farten og kan derfor ofte nå pasienten raskt - også i vedkommendes hjem. Dette krever gode varslingsrutiner.

Bevitnet hjertestans på offentlig sted burde være egnet for tidlig defibrillering. En studie fra København viste at defibrillatorer bør plasseres ved knutepunkter: jernbanestasjoner, områder med store folkemengder, kjøpesentre og busstasjoner, for å nevne noen (8). Samtidig erfarte man at defibrillatorer som var i nærheten ofte ikke ble benyttet, bl.a. fordi de ikke var synlig tilgjengelig der og da. Det kan derfor være nødvendig med lokal organisert respons, gjerne av frivillige i samarbeid med ambulansetjenesten. I en randomisert amerikansk studie med 19000 frivillige økte overlevelsen fra $14 \%$ til $24 \%$ dersom man hadde defibrillator (9).

De fleste tilfeller av uventet hjertestans skjer i hjemmet. En populasjonsbasert studie fra Skottland viste - kanskje nedslående - at siden de fleste hendelsene inntraff på steder der defibrillator likevel ikke ville vært tilgjengelig, vil effekten av et større utplasseringsprogram være marginal (10). I samme retning trakk det faktum at hvis defibrillator kunne vært tilgjengelig, vil også ambulansen komme raskt til stedet, nettopp fordi det dreier seg om et knutepunkt. Utplassering av defibrillator i hjemmet har ikke vist seg å være effektivt (11). Og defibrillatorer på større arbeidsplasser eller skoler vil neppe bety all verden, siden folk som jobber eller er under utdanning ofte er unge og friske. Men det kan være pengene verdt å ha muligheten til å redde et ungt liv.

Endelig må man spørre om utstrakt utplassering av defibrillatorer kan gjøre mer skade enn nytte. Det er lite som tyder på alvorlige problemer for bruker og/eller pasient. I hovedsak har det dreid seg om at apparatet ikke virket (12) eller var blitt stjålet (9).

Pasienter med primær ventrikkelflimmer kan utvilsomt reddes ved tidlig defibrillering, og utplassering av halvautomatiske defibrillatorer er skritt i riktig retning. For den enkelte kan det bety alt, men våre forventninger bør være realistiske.

Eirik Skogvoll

eirik.skogvoll@ntnu.no

Eirik Skogvoll (f. 1960) er overlege ved Anestesiavdelingen, St. Olavs hospital, og førsteamanuensis ved Norges teknisk-naturvitenskapelige universitet. Han har vært styremedlem i Norsk Resuscitasjonsråd siden 1997.

Oppgitte interessekonflikter: Ingen

\section{Litteratur}

1. Skogvoll E, Lexow K. Hjertestans - definisjon og forekomst. Tidsskr Nor Legeforen 2009; 129: $1351-2$.

2. Skogvoll E, Wik L. Active compression-decompression cardiopulmonary resuscitation: a population-based, prospective randomised clinical trial in out-of-hospital cardiac arrest. Resuscitation 1999; 42: 163-72.

3. Olasveengen TM, Vik E, Kuzovlev A et al. Effect of implementation of new resuscitation guidelines on quality of cardiopulmonary resuscitation and survival. Resuscitation 2009; 80: 407-11.

4. Valenzuela TD, Roe DJ, Nichol $G$ et al. Outcomes of rapid defibrillation by security officers after cardiac arrest in casinos. N Engl J Med 2000; 343: 1206-9.

5. Krav til bruk av defibrillatorer (hjertestartere). Rundskriv IS-5/2007. Oslo: Sosial- og helsedirektoratet, 2008

6. Drezner JA, Rao AL, Heistand J et al. Effectiveness of emergency response planning for sudden cardiac arrest in United States high schools with automated external defibrillators. Circulation 2009; 120: 518-25.

7. Whitfield R, Colquhoun M, Chamberlain D et al. The Department of Health National Defibrillator Programme: analysis of downloads from 250 deployments of public access defibrillators. Resuscitation 2005; 64: 269-77.

8. Folke F, Lippert FK, Nielsen SL et al. Location of cardiac arrest in a city center: strategic placement of automated external defibrillators in public locations. Circulation 2009; 120: 510-7

9. The Public Access Defibrillation Trial I. Public-access defibrillation and survival after out-of-hospital cardiac arrest. N Engl J Med 2004: 351: 637-46.

10. Pell JP, Sirel JM, Marsden AK et al. Potential impact of public access defibrillators on survival after out of hospital cardiopulmonary arrest: retrospective cohort study. BMJ 2002; 325: 515

11. Bardy GH, Lee KL, Mark DB et al. Home use of automated external defibrillators for sudden cardiac arrest. N Engl J Med 2008; 358: 1793-804.

12. Shah JS, Maisel WH. Recalls and safety alerts affecting automated external defibrillators. JAMA 2006; 296: 655-60. 